\title{
From conscious to unconscious and back. Remarks on Melanie Klein's interpretation of Magic Word
}

\section{Od świadomego do nieświadomego i z powrotem. Uwagi na temat interpretacji Magicznego slowa Melanie Klein}

Received: June 20, 2020

\begin{abstract}
The paper examines fluctuations between conscious and unconscious modes of mind functioning as outlined in Melanie Klein's interpretation of Magic Word (Klein, 1929/1948), using the double lens of psychoanalytic and semiotic concepts of symbol. The study aims to explore the process of transformation that takes place in conscious and unconscious parts of the mind, when the mind overcomes maniac defences and is confronted with core depressive recognition: a truth about separateness of individual, and all anxieties it arouses. The examination of conscious aspects of depressive position will be performed through the prism of Charles Peirce (1998) semiotic, while unconscious content will be explored according to Melanie Klein psychoanalysis. The results of the study reveal, that employment of psychoanalytic and semiotic perspective simultaneously, when examining dynamics of psychic position, allows to break down the process to smaller, but still explorable sequences. Such approach allows not only to study most distinctive elements of the position but also to track dependencies that occur between them in time on both conscious and unconscious level. Moreover breaking down depressive dynamic to the smaller sequences facilitates more careful monitoring of the disturbing influence of unconscious to consciousness when psychotic response picks up. Similarly, sequential view enables more precise identification of the point when triangle space returns, and so facilitates analysis of conditions associated with that important change.
\end{abstract}

\footnotetext{
${ }^{3}$ Cultural Studies at Wroclaw University, Poland.
}

Accepted: September 11, 2020

\author{
Written by: \\ Marta Iwaszuk $^{3}$ \\ https://orcid.org/0000-0002-7360-1769
}

\section{Podsumowanie}

Cel: Artykuł, używając podwójnej definicji symbolu: psychoanalitycznej i semiotycznej, analizuje opis fluktuacji umysłu pomiędzy świadomością i nieświadomością zarysowany przez Melanie Klein w jej interpretacji Magicznego słowa (Klein, 1929/1948). Badanie ma na celu eksplorację procesu transformacji, która następuję w świadomości i nieświadomości, jako odpowiedź na przekroczenie obron maniakalnych i konfrontację $\mathrm{z}$ rozpoznaniem sedna pozycji depresyjnej: prawdy o oddzielności jednostki wraz z wszystkimi lękami jakie ta prawda wzbudza.

Metoda: Badanie świadomych aspektów pozycji depresyjnej zostanie przeprowadzone przez pryzmat semiotyki Charles'a Peirce'a, zaś nieświadome treści będą badane zgodnie $\mathrm{z}$ teorią psychoanalityczną Melanie Klein.

Wyniki i wnioski: Wyniki analizy ujawniły, że zastosowanie podwójnej, psychoanalitycznej i semiotycznej, perspektywy podczas badania dynamik pozycji psychicznych pozwala na podzielenie zachodzącego procesu psychicznego na mniejsze, ale nadal nadające się do badania sekwencje. Takie podejście umożliwia nie tylko badanie elementów dystynktywnych dla poszczególnych pozycji psychicznych, ale także obserwację zależności, które pojawiają się między nimi na przestrzeni czasu na świadomym i nieświadomym poziomie. Ponadto podzielenie depresyjnej dynamiki na mniejsze sekwencji ułatwia staranniejsze monitorowanie zakłócających wpływów nieświadomości na świadomość, kiedy psychotyczna reakcja przyjmuje na sile. Analogicznie, widok sekwencyjny umożliwia bardziej precyzyjną identyfikację punktu, w którym trójkątna 
Keywords: depressive position, Hanna Segal, Melanie Klein, psychoanalysis, symbolism.

\section{Introduction}

The aim of the paper is to perform an analysis of the move, that the mind performs when it switches from more conscious operating modes to those dominated by unconscious, and how it further returns back to a more conscious setting. The base for the analysis will be a description of these fluctuations provided by Melanie Klein in her interpretation of Magic Word, that she included into her early paper Infantile anxietysituations reflected in a work of art and in the creative impulse (Klein, 1929/1948).

These moves of mind that are to be analysed: from unconscious phantasy (mainly paranoidschizoid position) to conscious recognition of actual, external world (mainly depressive position) are -according to Klein - at the core of mind development, for they match the unique internal world of the person with the environment of the individual, and so enable genuine, personal growth. In the paper these fluctuations will be examined through the lens of symbolism concept, and the choice of the perspective is grounded in two reasons. The first reason is close connection of the interpreted paper to the concept of symbol formation: Melanie Klein wrote the paper in 1929, at the time when she started to analyse Dick and so also at the time when impact of symbolization to ego development was emerging to her. As such, the paper is filled with multiple interpretations of symbolic meanings and their transformations in the two analysed cases, making the paper good fit for the topic. The second reason lies in methodology opportunities the symbol provides. It is very well grounded in the psychoanalytic field: Sigmund Freud introduced symbol as a core analytical tool at the beginning of his work and extensively developed it over time (Petocz, 2003), furthermore Ernest Jones (1918/2000) as well as Melanie Klein (1930/1948) vastly contributed to psychoanalytical understanding of the symbol. This solid theoretical framework is not the only advantage. For the purpose of this work it is equally important that from the start psychoanalysis considered symbol very broadly, an example here may be interpretation of hysterical symptoms as mute symbol, that refers to trauma. Such flexible concept - unarguably przestrzeń powraca, a tym samym ułatwia analizę warunków powiązanych $\mathrm{z}$ tą istotną zmianą.

Słowa kluczowe: pozycja depresyjna, Hanna Segal, Melanie, Klein, psychoanaliza, symbolizm.

necessary for unconsciousness examination goes very well with extensively explored semiotic definition of symbol, as provided by Charles S. Peirce. Furthermore, the match of psychoanalytic and semiotic view on symbol mirrors continuity between unconscious and conscious, that ego fluctuates between in order to maintain connection between the two. Preserving this continuity in the research model is a paramount for it gives well equipped tooling for examination regardless of the point of fluctuation. While psychoanalytic symbolisation concept covers, what an individual is trying to convey, the semiotic notion of symbol - with its variety of interpretant - outlines, what is communicable. In such a setting, serving conscious and unconscious aspects of communication, enables parallel interpretation and with that allows one to observe fluctuations in their graduality, by tracking how much conscious and unconscious component is in the conveyed meaning in a given moment. Such snapchats can further be tracked over time, and so picture the trends of the dynamic. Needless to say, such precision allows us to spot the moment of the switch, when one psychic position is left for another, since the moment, when the picture becomes clearly depressive or paranoid, becomes easy to grasp.

\section{Method}

The idea to read Klein's paper through the lens of symbolism in its psychoanalytical and semiotic dimensions is grounded in discoveries of Richardo Steiner, who first spotted and analysed the connection between the two perspective in his paper Does the Peirce's semiotic model based on index, icon, symbol have anything to do with psychoanalysis? (Steiner R. , 2007). In the paper he performed tentative linkage between semiotic concept of symbol and psychoanalytic (mainly Kleinian) understanding of symbolism, which allowed him to propose the following concept of intersemiotic function:

By 'intersemiotic function' I mean a function able to register all aspects of human 


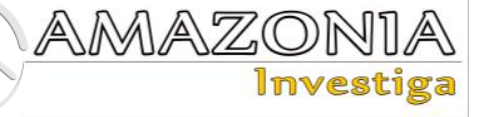

communication and able to make sense of them through verbal language and interpretation without losing contact with the immediacy of their non-verbal and pre-verbal components, related to all our perceptions, not only the acoustic or the visual ones (Steiner R. , 2007, p. 261).

In his paper Ricardo Steiner remains focused on categories (types) of symbol that are captured by psychoanalysis (symbol proper, symbol equation) and by semiotic field (index, icon,

\section{Klein \& Peirce findigs on symbol combined into psycho-semiotic model}

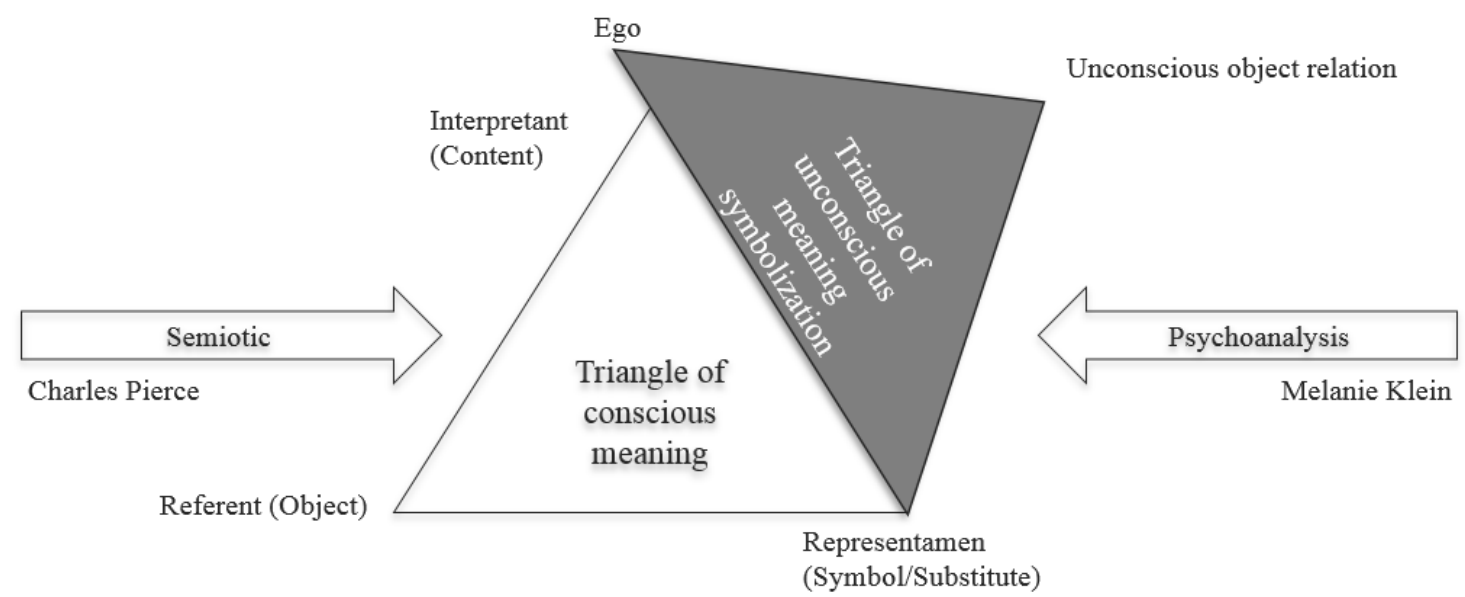

Figure 1: Psycho-semiotic model of thinking.

The psychoanalytic part of it covers the denotation, that the ego is able to capture with respect to substitute (representamen), meanings the substitute stands for (interpretant), and object (referent), 4 while being determined by constraints imposed by unconscious phantasy, that finds its expression in unconscious object relation (Isaacs, 2002). The psychoanalytical part of the proposed model describes then the mechanics, that the individual employs, when facing the immediate object and its place in semiotic code.

The semiotic part of the model describes the external aspect of semiotic activity, as it examines what and how is available in the code, as such. The semiotic part therefore is focused on two aspects: one is how the sign signifies, with

\footnotetext{
${ }^{4}$ I purposely skip here indication, that representamen consists of distinctive features, when observed through the prism of relations between elements of sign. That feature seems to constitute nature of cognition regardless of whether conscious
}

symbol). For the purpose of this analysis however much more useful is the very connection he manages to establish between conscious and unconscious aspect of semiotic activity of the mind. For the mutual influence between the two describes a simple, but comprehensive model of the mind, that serves both internal capabilities and external devices, that are at play in the act of thinking. This dynamic of mutual influence can be described in a form of two, combined triangles.

(Symbol/Substitute)

respect to its core elements and relations between them (Interpretant, Representamen, Object), and the other, which is how sign exists and transforms itself within a code (infinite semiosis). Both these semiotic spheres are central to the analysis, for they outline a scope of what is communicable.

\section{Theoretical Framework}

The paper Infantile anxiety-situations reflected in a work of art and in the creative impulse (Klein, 1929/1948), that was chosen for analysis was issued by Melanie Klein in 1929. It was a time, when Klein started to develop a comprehensive view on the topic of symbolism. Between 1929 and 1930 she had been analysing the role of creative substitution in respect to recognition and 
overcoming early anxieties in adulthood (Klein, Infantile anxiety-situtations reflected in a work of art and in the creative impulse, 1929/1948), she had been studying mechanics of substitution at children's play (Klein, Personification in the play of children, 1929/1948), and finally she formed the overall standpoint, that captured direct linkages between symbol formation and ego development (Klein, 1930/1948).

There are two cases, that Klein analyses in the Infantile anxiety-situations reflected in a work of art and in the creative impulse. The first of them is exploration of the work of art, namely content of Ravel's opera, based on the story Magic Word written by Sidonie-Gabrielle Colette ${ }^{5}$. The second case is the analysis of a brief episode of depression, that Ruth Kijar underwent and its linkage to the recognition of her natural talent to paint. Both topics, that Klein describes are interesting in their own way, but for the purpose of analysis of conscious and unconscious aspects of symbolisation, the case of Colette's story is more relevant. For, unlike Ruth Kijar paintings (which in scattered manner monitor progress of reparation of internal object), Colette's story captures the psychic dynamic as a whole: in one lecture the reader tracks the entire move from conscious to unconscious and back. And it is not only the matter of the big picture, that the reader is provided with, but also about the story's organising qualities, that enable this wholesome view onto the sequence of difficult, internal experiences. It seems, that Klein herself recognised this organising feature of Magic Word, as she decided to open her paper directly with Collet's story (which sketched the frame for the paper theme), and only afterward she moved to the analysis of the Ruth Kijar case. This organising feature is important for undertaken topic, for it aligns with nature of symbolisation, which is an ongoing process and should be examined with respect to changes, that occur in its duration, rather than as a set of selected and fragmented symbols, that can be linked on one or another token. In the analysis, I will therefore focus on the Magic Word case, for in this case the reader benefits twice: from Colette's ability to capture entire fluctuation in an artistic form (which was further refined by the framework of Ravel's opera) and from Melanie Klein's interpretation of this artistic insight.

\footnotetext{
${ }^{5}$ Klein for her analysis of the story uses review of the Ravel opera, that was played at the time in Vienna. The review was issued by Eduard Jakob and published in "Berliner Tageblatt".

${ }^{6}$ It is worth comment already at this point that according to the whole Klein theory, such reaction is typical refusal to
}

Magic Word tells the story of a 6 year old boy, that struggles with his homework. He expresses his disinclination in various ways, i.e. he bites his pen and says he doesn't want to do the stupid lessons. To escape from this unsuitable setting the boy engages is phantasy on alternative and more pleasurable ways of spending his time. ${ }^{6}$ So when he is sitting, dreaming and doing no homework his mom comes into room and asks, if he has done his lessons. Recognising the reluctance of the boy she tells him he shall have dry bread and tea with no sugar, and leaves. Mother's reaction only increases the boy's misery and as a result pushes him into rage: he puts out his tongue at his mother, he drums on the door, breaks the tea-pot and he tries to stab a squirrel (fortunately, when he opens the cage the animal manages to escape). He further seizes the cat and makes a lot of mess by breaking other things in the room. When more and more of his fury is released the maltreated objects seem to come to life and refuse to serve him. His alienation increases and the change in his environment is now overwhelming and terrifying. At some point the boy is no longer able to withstand the anguish and escapes to the park. This however does not free him from the hostile environment. On the contrary, in the park animals attack him and actually fight for who is to bite the child. In the fight the boy's squirrel falls down from the tree and boy instinctively takes off his scarf and binds up squirrels paw, while whispering „Mama”. The emotional colour of the situation immediately changes: animals recognise that he is a good boy, drop the fight and leave (sometimes calling "Mama").

The brief story of this presented libretto, Klein analyses in respect to three main components. The first component is an anal drive to express one's own aggressive impulses. The second component results from the first one and it is a recognition of the damage one's own aggression causes, the recognition that - if profound - must be followed by the move to more genital (caring) mode. The third component is related to the source of the breakdown, that the boy displays. According to Klein the origins of this collapse can be found in early, unmastered anxiety, that pulled anal drive for emergence and aroused aggressive impulses. This unmastered anxiety is considered to be a remnant of early stages of

work through depressive position. Since it comes down to recognition of separateness of the object. The boy, that does not want to do his homework, is in fact refusing to admit, that he is not self-sufficient and requires external world for his development. That is a regular obstacle of depressive position that children and adults encounter. (Segal, 2002) 


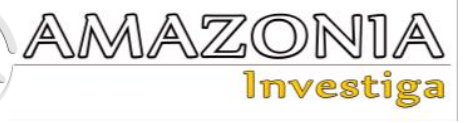

infant development, which explains the intangible nature of this overwhelming dynamic. Interestingly, she interprets this anxiety in terms of fear of castration and deep anxiety associated with the primary scene. Such an interpretation fits psychoanalytic discovery, that primary scene is at the core of thought, and that ability to think about internal and external reality is determined by ego capacity to overcome anxieties, that primary scene arouses and to adequately (in line with development stage) fulfil desires it confronts. Since in the analysed story the boy remains unable to accept the order, that creative couple of primary scene represents, and to start to learn, this inability must lead him directly to severe castration fears.

\section{Results and Discussion}

The psycho-semiotic model of thinking has for its base individual psychic world with all its capabilities and constraints, it therefore presents how the individual in a certain moment of psychic position uses language and other symbols for thinking (while acknowledging through semiotic triangle, that available code is both: limited (in given point in time) and in constant development). As indicated in the model, consisting of symbol triangles based on Peirce and Klein theories, it is a role of ego to mediate between - represented symbolically unconscious object relation, that ego itself is submitted to, and reality demands that ego represents to itself in a form of signs. The result of the mediation is individual comprehension of symbol. In the process of mediation the main task of the ego is to ensure connection between unconscious and conscious meaning, as this is a prerequisite for making the object important to a person. The overall mediation however is subjected to the more relevant aim to respond to reality demands, and so it makes all the difference whether it is conscious or unconscious space that dominates the symbol recognition. For developmental purposes it is ideal, when good balance between conscious and unconscious is kept (Steiner J. , 2005) and so excessive defences are mainly withdrawn (Klein would situate it closer to depressive position (Segal,, 2002). If on the contrary- excessive defences start to dominate and flood the ego (and these defences are mainly splitting and -resulting from splitprojection) the mind becomes immersed in unconscious and gradually loses accurate reality perception paranoid-schizoid position (Segal, 2002). The remaining question is then, how dominance of each position can be recognised?
Paranoid schizoid position becomes apparent, when projection and splitting come into play. And this can be captured by various symptoms, which indicate, that good sense of separateness between ego and object is being lost. Without that distinction, the individual inevitably loses further capacity to differentiate between conscious and unconscious content, and between internal and external factors. In the Magic Word, the beginning of losing differentiation between ego and object can be spotted already at the start of the story, when the boy refuses to do the homework and puts out his tongue at his mother. He signs up to himself and his mom, that he does not need contact with external reality. Obviously, that demonstration also reassures him, that he is very right in his decision, which only facilities his unconscious drives to captive the ego (and worth remembering, that the ego is the only source of differentiation between conscious and unconscious). The dynamic gains in strength and boy starts to lose ability to differentiate between internal and external. This happens because splitting and projection, which were present already in the boy's reluctance to do the homework and in his rejection to maintain meaningful communication with his mother, are now not restrained by ego and external reality. As ego weakens, projection gradually starts to dominate, and that severely disfigures perception of reality. The initial, unpleasant setting, that put onto the boy the expectation of doing boring homework, turns now into attacking the environment: the boy perceives room's equipment to come to life in order to attack and torture him. All these examples outline how paranoid - schizoid position can be identified.

Depressive position, in turn, can be recognised by no (or very few) signs of splitting and projection. Absence of these defences will be indicated by signs of good sense of separateness between ego and object, by ego ability to benefit from external resources for its development, by ego capacity to introduce to the external world meaningful internal elements and by undisturbed abstract thinking. In Magic Word depressive position is the most prominent in that pivotal moment, when the boy switches from unrestrained fury to a caring mode. The moment, when boy bandages the squirrel's paw is pivotal, because he was finally able to recognise the destruction, that comes from his own anger. The recognition was possible, because the indirect wound did not strengthen his defences and facilitated the so called triangle situation, which allowed him to observe simultaneously himself and the object of his actions through so called observing ego. Therefore, when wound of his 
animal informed him about his own anger, that recognition put to work guilt and need for reparation (and triggered reaction to bind the squirrel's paw). In this brief moment multiple changes occur and from blinding anger emerge: recognition of fury (which indicates return of differentiation between conscious and unconscious), recognition of a wound (which informs on regained distinction between internal and external) and recognition of his own squirrel (which proves distinction between ego and object was reinstalled). All these crucial changes result in ego being more capable to source from external, or - putting it in Peirce term's - from Interpretant. Up until the moment, of the squirrel's wound recognition, boy remained entirely uninformed on external results of his action and the only information, that preoccupied his mind was fear of growing anger and so growing anxiety. In other words he was deeply immersed in his own unconscious phantasy and focused on his struggle with devastating, unconscious object relation Once he was finally able to see through his anger and fears and to recognise the results of his action, he could relate to them accordingly. All these changes - in operating model available to the boy - are interconnected with the overall capacity to think. With reestablishment of core distinctions, comprehension of symbol became complex and ready for abstract thinking, this can be spotted in boy's return to linguistic world and in a usage of the word "mama", which stands not only for the mother of the boy, but also for a humane attitude along with capability to care about external objects. It is therefore the mother with all her functions, and in that (semi-)abstract form can further be transposed to any individual or event, that prove caring to be possible. Furthermore, it is also a remarkable representation of abstract thinking, for in that pivotal moment the mother, despite her physical absence, becomes available to the boy's mind. What could not take place at the beginning of the story, when the physically present, but frustrating mother could not be recognised in her loving attitude, could be done once unconscious content became more apparent to the boy .

All these indicate, that in the initial Klein interpretation, her later concepts can be mapped so to recognise in the story the entire fluctuation: from edge of depressive position into a paranoid schizoid mode and back to more depressive functioning. The original interpretation, that sees the story as an attempt to transgress anal phase into the genital stage, can therefore be further broken down to track the dynamic of this attempt: the growth of hatred towards reality, that pushes the boy out of conscious functioning into a position, where he is entirely overwhelmed by unconscious phantasy and the fears it arouses, up until the moment when he is finally able to recognise his aggression, and so take over the ownership of his hatred and manage it according to ego demands. It is worth taking a closer look at each step of this fluctuation and analyse both switches, that occur along with accompanying saturation with unconscious phantasy, that obviously - changes constantly throughout the story.

\section{Regular depressive position setting.}

The story starts from a very regular picture of the boy, that is to do his homework. It is still much depressive setting, where conscious part dominates. It is clear what and why boy must do, and what could be the consequences of refusing to learn. Ego performs its natural role to ensure external and internal requirements are recognised and responded to. Yet, while the external reality is well recognised the internal (especially unconscious) part remains beyond ego's reach. As a result the boy is unable to combine successfully external demands with internal drives. His mind is more and more keen to escape the effort that an external world tries to put on him. This is the clear colour of unconscious forces, which unmastered by ego, are keen to cease contact with the external world, and so cause the withdrawal to unconscious.

Boy's maniac response to the setting, which confronts him with the fact that he is not selfsufficient.

Because the paranoid-schizoid object relation takes on its importance (boy does not engage in homework in any capacity) maniac defences are gaining in strength. This causative relation finds its grounds in the nature of maniac defences, which essentially are a remnant of paranoidschizoid defences: projection and splitting. The difference between maniac defences and splitting $\&$ projection lies in the extent to which contact with reality is kept. While maniac defences tend to take the shape of a bubble, that isolates an individual from unwanted input (external or internal), the match of splitting and projection by default malforms perception of internal and external reality according to unconscious phantasy and confuses ego with object making impossible identification of internal urges.

Maniac response gains in strength and so splitting and projective identification comes into play. 


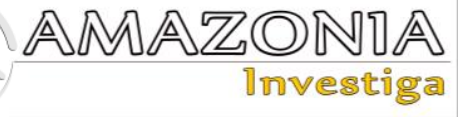

In the story, boy's maniac response to the demand to learn only increases. Excessive maniac response introduces projection and splitting, which take the boy into paranoidschizoid position. Worth remembering, that splitting and projection are means for unconscious phantasy to take a control over ego. The symptoms, that these defences operate, are: difficulties to make a distinction between internal and external, ego and object and so between conscious and unconscious. Within the story increase in splitting and projection is presented through an expression of anger towards environment (i.e. kicking the door, breaking the pot), for all these activities cannot be justified as reasonable, and yet the sense of differentiation between internal and external is still partly kept.

\section{Projection hits the level when separateness is lost (boy's anger is now aimed at the environment)}

Release of growing anger must bring a peak in anxiety, which translates to increase in splitting and projection. When projection hits the level, that makes ego excessively infused with unconscious phantasy, sense of separateness is lost. Aftermath of this can be observed in core symptom boy displays: he is unable to capture into conscious his unconscious anger despite excessive expression of the devastation that took him over.

\section{Boy is now in fear of his own anger projected onto environment.}

According to released (acted out) unconscious phantasy, the surrounding is now seen, as hostile and even attacking, for the boy disowns his anger and stores it outside of himself. This -perceived as external- hostility causes severe anxiety in boy, who - being misled by projection - finds himself in real danger. Yet, it is necessary to add, that attribution of his own anger to the environment allows the boy to relate to his anger and fight it back (though indirectly).
Anger (and so fear) hits the level, when remnants of order are overtaken by chaos.

Despite multiple attempts, the boy cannot prevail over "hostile" environment and residing in such "angry" surrounding stirs in him enormous fear. With further increase of anger (and so of fear) the boy collapses into chaos and escapes from room to the park in search of external order.

\section{Escape from uncontrolled persecution.}

At this point it is worth adding one remark. This escape seems primarily to be a rescue from a persecuting environment. However it can also be interpreted, as escape from unlimited persecution, that may occur only, when unconscious takes over the control. It can therefore be interpreted as an escape from overwhelming unlimited unconscious anger (be it his own or his environment) in search for external order, that could cease such nonprospective conditions.

\section{Maintenance of employed defences results in repetition of attack in new circumstances.}

In the park, where the boy escapes to, he does not find new order, but only repetition of attack. That is because the phantasy of self-sufficiency does not decrease and so the external world remains rejected regardless of whether the boy is in need of it. It is certainly a step forward, for unlike at the start when the boy did not want to learn, he seems now to establish a contact with epistemophilic drive ${ }^{7}$. However, despite the regained will to learn, the boy remains unable to benefit from any order (be it external or internal). The reason for that lies in the solution he implements, to avoid collapse into deep psychotic breakdown, that would remove any understanding. The solution that boy implements, namely attribution of his anger to the environment, allows him to keep on the radar his own psychotic part and - though indirectly to confront it. This urge to stay in touch with the psychotic symptoms -although protects the ego from further fragmentation- impedes benefiting from internal and external reality for both are

analysis of possible disruptions that might impede benefiting from epistemopilic instinct see Florence Guignard most recent book (Guignard, 2019). To further understanding of epistemophilic instinct in context of presented story it is worth to suplement it with Kleinian view onto a destructive aspects of narcissisim and its connections to envy as proposed by Riccardo Steiner in his paper On Narcissism. The Kleinian Approach (Steiner, 1989).

\footnotetext{
7 Epistemophilic instinct is an important dimension of
presented dynamic, there is however not enough space in one

7 Epistemophilic instinct is an important dimension of
presented dynamic, there is however not enough space in one paper to explore this aspect of overcoming anal stage. For more information on epistemophilic instinct see Melanie Klein paper on symbol formation (Klein, The importance of symbol formation in the development of ego, 1930/1948), and Wilfred Bion book on learning from experience, where epistemophilic instinct is seen as part of broader system of linkages the mind creates (Bion, 1984). For comprehensive
} 
severely malformed by unconscious phantasy of ceaseless anger.

\section{Triangle situation ceases excessive projective identification.}

Only after the squirrel is accidently wounded is the boy able to retrieve triangle situation (establish linkage between observing ego, object of his actions and himself in action). When the triangle situation occurs it is clear, that boy is back in depressive position (it is a proof, that object and ego are well differentiated). This significant change is worth explanation, for how did it happen that the triangle situation occurred, after a stream of excessive projective identification? It seems, that the accidental wound of an animal, that the boy once intended to hurt, allowed him to see himself in an action without the burden of excessive guilt, which intentional hurt would cause (and so which would trigger increase in splitting). In other words, these circumstances allowed him to incorporate his anger to ego and respond to it (which equals withdrawal from unconsciously driven actions).

There is perhaps one more thing to add on this transition: it is the boy's squirrel, that is being wounded. The new environment facilitated differentiation between part of reality he felt connected to from those that remained neutral in that respect. That differentiation could not take place in the boy's room, filled with his belongings. Only after he escaped to park, he could see and learn that difference in concrete, bodily form. And the sense of belonging is one of the core components facilitating move to depressive position for the linkage between ego and object - by its very nature - undermines splitting and secures its withdrawal upon the occurrence. (It is harder - but not impossible - to store unwanted parts of the ego in an object that is perceived as linked to ego.) This impact of matter of belonging to the occurrence of triangle situation remains in line with Klein stressing relevance of loving feelings in working through Oedipus complex (Klein, 1948).

\section{Benefiting from separateness (reparation)}

When the boy binds up the paw of wounded squirrel he is finally able to relate to his external environment in a meaningful way, and therefore without hostility. Separateness, that initially was a source of tough and demanding requirements, now becomes an opportunity for the boy to express his goodness towards his environment.

\section{Launching a set of associations with good and meaningful outside world (Mama)}

Finally, the consciousness seems to dominate again. To fully display the change, the boy whispers the word "Mama" when taking care of the wounded animal. The whisper of the boy, when caring for the squirrel, is a proof of reestablishing linguistic picture of the world, that is oriented to external and good objects. Such an interpretation is embedded in the plot itself, and further highlighted by Klein. What is to be added, is that it is not only a matter of retrieving the whole object relation (psychoanalysis), but also a matter of retrieving (re-establishing), a set of linkages between Interpretants (semiotic), that on a conscious level protect maintenance and development of such object relation. Worth remembering, that according to Charles S. Peirce (1998) sign is defined by a set of other signs, that describe it. All these signs, that create definition of a selected sign are subject to the same process (so are defined by further sets of other signs) ad infinitum (unlimited semiosis). There is therefore a complex and extensive system in place, that holds shared meanings for the language user. That external holding must be taken into account, when object relation is considered. The close bond between individual psyche and language is clearly outlined in the story: the change that took place in the unconscious part of mind can be tracked in conscious expressions. The tongue, that the boy initially put out to reject mother, was finally used in a refined way to join the linguistic world and establish and maintain meaningful connection with reality through the whispered word. At this point it should be noted, that neither language nor human psyche are static, therefore the set of connections that the boy establishes between conscious and unconscious, external and internal, collective and individual, is subjected to development process. It matures with object relation maturation, which in turn depends on semiotic devices, as they outline what is communicable. It is therefore mutual nourishment in this growth dynamic: object relation develops with growing span of thinkable and so communicable (enhancement of the code and its usage), and growing span of thinkable and communicable (unlimited semiosis) is possible only through multiple angles referent is perceived and used by individuals (and that is secured by development of object relation). This mutual nourishment however does not describe the entire situation of animal symbolicum (Cassirer, 1974), for there is always a space of unnamed and unacknowledged, that remains within a person, within a code and between the two. This unknown space underlies and 


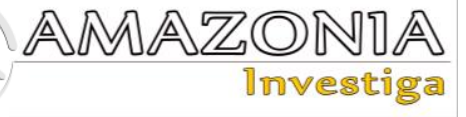

determines every exploration of human condition, and by that it is perhaps the most important seam of the psychoanalytic and semiotic symbol triangles.

\section{Conclusions}

Implementation of intersemiotic communication concept (Steiner R. , 2007) and psycho-semiotic model to the analysis of Melanie Klein interpretation of Magic Word allows us to recognise value brought by examining conscious and unconscious in parallel. While unconscious dynamics remain the primary determinant of the individual psychic world, introduction of conscious, semiotic activity to the picture adds continuity to the process performed by ego. In psychoanalytic terms, such parallel examination of conscious and unconscious, provides a sort of holding (Winnicott, 1987) to the analysis, securing that analyst mind is led by provided material and not the other way around.

Furthermore combining psychoanalytic and semiotic devices enables placing significant changes, that occur in unconscious part, onto the linear mind expressions (enforced by the nature of object relation). And that amendment is not a trivial one, for it removes from examination unconscious phantasy on unlimited, and facilitates switch from symbol analysis to language analysis (move from what elements are available in language, to what relations can be created between them). The aftermath of the adjustment is twofold. For theoretical framework part, it improves understanding of core psychoanalytic notions, since with that shift, the grammar of unconscious, that Freud so skilfully sensed, becomes more available to scientific exploration. On practical ground, the step not only enforces reality principle in examination (recognising that only limited amount of signs can be communicated at the time, regardless of unconsciousness' richness), but also measures the capability of individual to encounter the depressive recognition of separateness: an acknowledgement on linear and hence limited nature of human condition.

Last but not least it is worth noting, that such parallel mind examination seems also to be led by certain rules: all the unconscious part of the dynamic outlined in Magic Word could only be analysed through monitoring how unconscious object relation impacts ego, and so for that part analytic tooling is central, however with switch to the triangle situation, when ego regains control, what is available for thinking and communicating in language code becomes a paramount. The fact, that it is only a small part of the story, when the boy actually comes into conscious mode, should not be misleading, for it is that brief moment, when the developmental milestone occurs and more importantly can be taken forward. For - on a meta level - the whole story tells about the inability to learn: to benefit from external as well as internal resources due to aggression and rage mixed with separation anxieties.

\section{References}

Bion, W. R. (1984). Learning from experience. London: Karnac.

Cassirer, E. (1974). An Essay on Man: An introduction to a Philosophy of Culture. New Heaven: Yale University Press.

Guignard, F. (2019). Psychoanalytic Concepts and Technique in Development. Psychoanalysis, Neuroscience and Physics. London: Routledge. Isaacs, S. (2002). The Nature and Function of Phantasy. In J. Riviere, Developments in Psychoanalysis. London: Karnac. (pp. 67-121) Jones, E. (1918/2000). The Theory of Symbolism. In E. Jones, Papers on PsychoAnalysis. Londyn: Karnac Books. (pp. 87-144) Klein, M. (1923/1948). The role of the school in the libidinal development of the child. In M. Klein, Contributions to psycho-analysis. London: The Hogarth Press. (pp. 68-86)

Klein, M. (1929/1948). Infantile anxietysitutations reflected in a work of art and in the creative impulse. In M. Klein, Contributions to psycho-analysis. London: The Hogarth Press. (pp. 227-235)

Klein, M. (1929/1948). Personification in the play of children. In M. Klein, Contributions to psycho-analysis. London: The Hogarth Press. (pp. 215-226)

Klein, M. (1930/1948). The importance of symbol formation in the development of ego. In M. Klein, Contributions to psycho-analysis. London: The Hogarth Press. (pp. 236-250)

Klein, M. (1948). The Oedipus Complex in the Light of Early Anxieties. In M. Klein, Contributions to Psycho-Analysis 1921-1945. London: The Hogarth Press. (pp. 339-390)

Peirce, C. S. (1998). Essential Papers. Bloomington: Indiana University Press.

Petocz, A. (2003). Freud, Psychoanalysis, and Symbolism. Cambridge: Cambridge University Press.

Segal, H. (1990). Notes on Symbol Formation. In H. Segal, The Work of Hanna Segal. A Kleinian Approach to Clinical Practice. Northvale: Jason Aronson Inc. (pp. 49-69) 
Segal, H. (1998). "The importance of symbol formation in development of ego" - in context. Journal of child psychotherapy (3), 349-357.

Segal, H. (2002). The Depressive Position. In H. Segal, Introduction to the Work of Melanie Klein. London: Karnac. (pp. 67-81)

Segal, H. (2002). The Paranoid-Schizoid Postion. In H. Segal, Introduction to the Work of Melanie Klein. London: Karnac. (pp. 24-38)

Steiner, J. (2005). The equilibrium between the paranoid-schizoid and the depressive positions. In R. Anderson, Clinical Lectures on Klein and Bion. London: Routledge. (pp. 45-56)
Steiner, R. (1989). "On Narcissim. The Kleinian Approach", Psychiatric Clinics of Nort America (3), 741-770.

Steiner, R. (2007). Does the Peirce's semiotic model based on index, icon, symbol have anything to do with psychoanalysis? In G. Ambrosio, S. Argentieri, \& J. Jorge Canestri, Language, Symbolization and Psychosis: Essays in Honour of Jacqueline Amati Mehler. London: Karnac. (pp. 219-272)

Winnicott, D. W. (1987). The child, the family, and the outside world. . Cambridge: Perseus Publishing. 